\title{
Diction as a Representation of Indigenous People in Indonesian Short Stories of Bobo Children's Magazine
}

\author{
Ika Nurhayani ${ }^{1}$, Muhammad Rozin ${ }^{2}$ \\ \{inurhayani@ub.ac.id ${ }^{1}$, rozin.muhammad@ub.ac.id² \\ Universitas Brawijaya, Indonesia ${ }^{1,2}$
}

\begin{abstract}
This paper aims to investigate the representation of indigenous people in Indonesia in short stories of Bobo children's magazine by describing what and how indigenous people are represented through diction in the short stories. The paper uses qualitative content analysis to analyse the short stories as texts and to discover the types of indigenous people represented with diction in the stories. The authors found two short stories about indigenous people of Dieng Plateau and Nias. The findings show diction of the stories is mostly informal and colloquial Indonesian and indigenous terms used in the short stories were limited to several words related to places, specific food, names of rituals, instruments of the rituals, and dances. The current research thus has filled the gap by providing findings related to the indigenous diction used in short stories of children's magazine in Indonesia.
\end{abstract}

Keywords: Diction, Indigenous People, Indonesia, Children, Short Stories

\section{Introduction}

Indigenous people are often marginalized in modern society. Htun and Ossa [1] show that indigenous groups in Bolivia only received a mere $5 \%$ of parliamentary seats. Dahl [2] mentions that indigenous people from four continents all underwent similar experiences with colonialism and similar discrimination at the hands of people who form the national culture and its institutions. Bartels [3] discusses over-policing over indigenous women in Australia which causes them to have a high rate of imprisonment for minor offenses.

Indigenous people are also marginalized in literature, notably in children's literature. Metzer [4] wrote about scholars' concern on the depiction of Native Americans in classic children's book such as in 'Little House on the Prairie' by Laura Ingalls Wilder, which was published in 1935 and 1953. The book wrongly described Native Americans as primitive and naked. Moreover, children literature who include narratives on indigenous people are sometimes not in favor of those people because they incline to instill national identity [5].

The marginalization of indigenous people is detrimental to the children of the people. Dobrow, Gidney and Burton [6] point out that media misrepresentations of ethnic groups can cause confusion about aspects of their identity among children of these groups. This can lead to these children having psychological problems such as low self-esteem. Therefore, proper representation of ethnic groups in the media, especially in children's literature, is very important for the process of identity construction among the children of the ethnic groups. 
Children's stories are different from adult literary books in that they are written using different skills and are aimed at the needs of children which are different from those of adults. Therefore, children's books cannot be studied with the same standard as adult books. To study children's books, it is necessary to develop specific techniques, methods and strategies [7].

Children's story is the kind of fiction that is intended for children. At first, children's stories were folk tales and fairy tales that people began writing in the 18th century in the West [8]. Children's stories are also the most widely circulated form of fiction internationally. For example, the famous Pippi Longstocking story book by Astrid Lindgreen from Sweden, the Japanese manga popular in many countries, and JK Rowling's Harry Potter book from England can be found from China to Peru [9].

In general, children's stories can be identified by three criteria [10]. First, the main characters are children or adolescents. Second, they center on simple themes or ideas, conflicts, and use simple language. For example, classic stories like Gulliver's Travels are accepted as children's stories because of the simplicity of ideas, relationships between characters, and language. Third, children's stories are often intended to convey moral messages.

From the aspect of word choice and syntax, in general, almost all stories of children and early adolescents are characterized by simple word choices and grammar, including rightbranching sentences where clauses are combined with coordinative conjunctions, temporal subordinate conjunctions, or causality. The use of qualitative adverbials and figurative language in children's stories is usually very limited [11].

There have been many works discussing specifically about the advantages of introducing literature to children, one of which is the book entitled Through the eyes of a child: An introduction to children's literature by Norton and Norton [12]. Here they argue that children's literature enables children to develop their cognition by providing them the opportunity to respond to literature and give opinion about the topic; children's literature provides an opportunity for children to learn about their own cultural heritage and the cultures of others as this is necessary for the process of social and personal development; children's literature assists children in developing their emotional intelligence because stories contain various moments of crisis when characters make moral decisions and contemplate for the decisions they make; children's literature is very valuable as it can be the major means of transmitting the literary heritage from one generation to the next.

Unfortunately, not much has been done to study the representation of indigenous people in Indonesian children literature. Most research on children's stories in Indonesia focus on developing children's characters using children's stories. As an example, is the research of Rohmah [13] which discusses the importance of children's stories in teaching the values of humanity to children. Furthermore, Nufus [14] discusses how to develop Javanese children's books for children's character education in a family setting. In addition, Ikhwan [15] discusses efforts to develop children's character by using children's literature in elementary school.

Therefore, this paper discusses the representation of indigenous people in Indonesia in children's short stories of Bobo, a top children's magazine in Indonesia. The short stories were taken from Bobo's editions published in 2020. Stories related to indigenous people were then selected and then analyzed using qualitative content analysis and Stephens' [11] framework which looks into diction, morphosyntax, figurative language, cohesion and social aspects of a children's literature. The current work focuses on the diction in children's short stories.

Hence the research questions of the following paper are as follows: (1) what indigenous people are represented in children's short stories in Bobo magazine and (2) how are indigenous people represented through diction in children's short stories in the Bobo magazine? 


\section{Research Method}

The current paper applied qualitative content analysis as an approach to investigate short stories as documents or texts, emphasizing the role of the investigator in the construction of the meaning of and in texts [16]. Furthermore, qualitative content analysis allows categories to emerge out of data [16]. The current paper also aims to describe categories of diction used in children's short stories of Bobo magazine. In addition, the framework of Stephens [11] was used to describe the types of diction used in children's short stories in Bobo magazine.

The original Bobo was first published as a children's magazine in the Netherlands by Blink.nl. The franchise was then bought by Jakoeb Utama, the founder of Kompas, one of Indonesia's top news outlets. The Indonesian Bobo was first published in 14 April 1973 [17].

The short stories investigated in this study were taken from Bobo's editions published in January to April 2020. There are 13 short stories in the editions. This publication year was chosen in order to display the most current data about diction in children's short stories in Bobo magazine. Bobo was chosen because the magazine is the oldest and the most popular children's magazine in Indonesia. The data was then observed based on the use of the diction in the stories using Stephens' [11] theory which offers a comprehensive tool to analyze children' short stories.

\section{Result and Discussion}

Out of 13 short stories, the authors found two short stories discussing indigenous people in Bobo's magazine of January-April 2020 editions. The indigenous people discussed in the two stories are Dieng and Nias' people. The story about Dieng is entitled Laras si Ongklok 'Laras the Ongklok' and the story of Nias is entitled Tarian Ya'Ahowu Halia 'The Dance of Ya'Ahowu of Halia'. Since the total stories of the editions are 13, the percentage of the stories on indigenous people is of $15 \%$.

Dieng is a plateau in Central Java. The name Dieng is a blending from two Sanskrit words, $d i$ 'a high place' and hyang 'the domain of the gods' [18]. Dieng has been attracting people's attention for centuries due to the discovery of ancient Hindu temples on the plateau. There were originally 400 temples in the area but only eight survived to this day [19]. This raises a theory that the Dieng plateau was a center of Hinduism in the 8th century [18]. Today Dieng has become a center of potato farming and a popular tourist destination. Besides its ancient temples and its scenic views, tourists are also drawn by unique rituals such as the famous dreadlocks cutting ritual. Children who are born with dreadlocks are seen as a blessing by the community of Dieng and therefore receive a special treatment in the form of dreadlocks cutting ritual [20]. Before the ritual, any wish a child with dreadlocks asks will be granted by the parents. Afterwards, the dreadlocks can be cut by a community leader and the hair is then floated in local waterways. The dreadlocks cutting ritual is now a part of the Dieng Culture Festival held annually in the area [20].

On the other hand, Nias is located 70 miles from Sumatra's West Coast with the population of 215,000. An Arab scholar, Edrisi, was the first person who gave an ethnographic description of the tradition of the Nias people in 1154. The Dutch colonized the island from 1825 until the Japanese occupation in 1942. The people of Nias are rich with tradition such as its traditional rectangular and oval shaped houses and its festivals and ceremonies [21]. Hombo Batu or stone wall jump is one of the most important rituals in Nias. Hombo Batu originated from Nias tradition to prepare its youths to be skillful combatants in case if any conflict with neighboring 
tribes occurred. For this purpose, young men were trained to infiltrate the defense of the enemies among others by jumping over the stone wall protecting the enemies' village. The training was in the form of Hombo Batu. During the Hombo Batu, young men must jump over a stone wall of 2,3 m height. In the modern time, the Nias people lead a peaceful life and Hombo Batu has been transformed into a traditional ceremony performed by Nias youths for festivals or celebrations [22].

In addition, the authors found three types of diction in the two short stories about Dieng and Nias people. The first one is informal diction in Indonesian. Informal diction uses everyday language according to grammatical rules of Indonesian and is found in the narrative of the stories.

(1) Setelah melihat upacara pemotongan rambut gimbal, Laras kembali ke warung Ibu. (Dieng)

After watching the dreadlocks cutting ceremony, Laras returned to her mother's food stall.

(2) Embun di Dataran Tinggi Dieng mulai membeku. (Dieng)

The dew on the Dieng Plateau started to freeze.

(3) Gerakan burung ditarikan dengan gemulai. (Nias)

The movements of the birds were transformed into a dance gracefully by the dancers.

(4) Hari-hari selanjutnya, Mama dan Halia berlatih sambil melihat video. (Nias)

In the following days, mother and Halia practiced the dance while watching the video.

The second one is colloquial diction which uses words related to non-standard dialects of Indonesian due to the influence of regional languages in Indonesia. The colloquial diction was found in the dialogue of the characters in the stories. In the stories, the colloquial diction is influenced by the Jakarta Indonesian dialect. The Jakarta Indonesian dialect is shown by particle kok and the use of negation enggak.

“Aku bangga, kok, jualan mi ongklok” (Dieng)

I am proud, really, to sell ongklok noodles.

(6) “Hi, Chika, kamu enggak bawa bekal?”, tanya Laras. (Dieng)

Hi, Chika, you don't bring any lunch with you?", asked Laras

"Tapi Ma, Halia enggak ngerti bahasa Nias" (Nias)

"But Mom, Halia does not understand Nias language"

The third one is diction from the indigenous people in Dieng and Nias which are limited to places, specific food, names of rituals, instruments of the rituals, dances, and a few words from the vocabulary of the indigenous people. There are eight words and one phrase representing Dieng and Nias people in the two short stories about Dieng and Nias in Bobo's magazine. This number is very limited because each of the short stories consists of two pages or around 500 words.

(8)

$$
\text { rituals }
$$

pemotongan rambut gimbal (Dieng) hombo batu/lompat batu (Nias) instrument of rituals

canang (Nias)

\author{
'a ceremony of dreadlocks cutting' \\ 'stone wall jumping' \\ 'a traditional musical instrument'
}


(10)

jubah, mahkota emas, sirih (Nias)

dance

ya'ahowu (Nias)

food

mie ongklok (Dieng)

words

baga-baga nonogu (Nias)

places

candi Arjuna 'robe, crown of gold, betel'

'a traditional welcome dance of Nias'

'a traditional noodle dish of Dieng'

'very pretty'

'the temple of Arjuna'

Canang in Nias is called Faritia. Faritia is a musical instrument made of metal or brass and is classified as an idiophone. Faritia has a diameter of $23 \mathrm{~cm}$, a thickness of $4 \mathrm{~cm}$, and a protruding center. Faritia is played during a dance or a traditional ceremony. The robe and the golden crown are worn by a woman attending a traditional ceremony [23]. The robe is red and yellow and is made of cotton. The crown is made of golden coins and the center back is adorned with golden flowers and leaves. Lastly, Ya'ahowu is a Nias welcome dance and is performed to welcome special guests in a party, a ceremony or an official visit. The dance is accompanied by a traditional song or sinuno in Nias language [24].

On the other hand, mie ongklok or ongklok noodle is a popular dish of Dieng Plateau. The dish consists of boiled noodles mixed with cabbage pieces, chives, and starchy gravy. Mie ongklok was invented by a local noodle vendor called Munadi. Mie ongklok is usually eaten with side dishes such as satay and tempeh [25].

Arjuna is the oldest and biggest temple in Dieng plateau. Arjuna temple was built to be a shrine of Siva. The temple used to have a linga sculpture inside. Linga is a symbol of Shiva. In fact, the whole complex of Dieng temples is dedicated to Shiva and the area used to be the center of Hinduism in Central Java [19].

\section{Conclusion}

In sum, the authors found two short stories about indigenous people of Dieng Plateau and Nias. The findings indicate that the diction of the stories is mostly informal and colloquial Indonesian. Indigenous terms used in the short stories were limited to places, specific food, names of rituals, instruments of the rituals, dances, and a few words from the vocabulary of the indigenous people.

It can be concluded that there are efforts to use diction related to indigenous people in the short stories of Bobo magazine published in 2020. However, the terms in the diction are limited and Indonesian formal and colloquial diction are still dominant in the short stories. Hence the current research has filled the gap by providing findings related to the indigenous diction used in short stories of children's magazine in Indonesia. Future research on related topics should look into more publication years to discover if the findings are indeed the trend in stories of a children's magazine.

\section{References}

[1] M. Htun and J. P. Ossa, "Political inclusion of marginalized groups: indigenous reservations and gender parity in Bolivia," Polit. Groups, Identities, vol. 1, no. 1, pp. 4-25, 2013.

[2] J. Dahl, The indigenous space and marginalized peoples in the United Nations. Springer, 2012. 
[3] L. Bartels, "Indigenous women's offending patterns: A literature review," Res. public policy Ser., no. $107,2010$.

[4] L. I. Wilder, Little house on the prairie. Wildside Press LLC, 2020.

[5] I. Ibaceta, "Chilean Children's Literature and National Identity: Post-Dictatorship Discourses of Chileanness Built through the Representation of Indigenous People," Bookbird A J. Int. Child. Lit., vol. 52, no. 3, pp. 53-64, 2014.

[6] J. Dobrow, C. Gidney, and J. Burton, "Why it's so important for kids to see diverse TV and movie characters," Conversat., vol. 20, 2018.

[7] L. Newbery and Y. Coppard, Writing Children's Fiction: A Writers' and Artists' Companion. A\&C Black, 2013.

[8] R. Trites, "Images of Growth: Embodied Metaphors in Adventures of Huckleberry Finn," in Representing Children in Chinese and US Children' Literature, C. Nelson and R. Morris, Eds. Burlington: Ashgate Publishing, Ltd., 2014.

[9] M. R. Morris and C. Nelson, Representing children in Chinese and US children's literature. Ashgate Publishing, Ltd., 2014.

[10] C. R. Obi, A. Alhassan, and U. S. Osuji, Children's Literature. Lagos: National Open University, 2010.

[11] J. Stephens, "Analysing texts for children: Linguistics and stylistics," Underst. Child. Lit., pp. $56-68,1999$

[12] D. E. Norton and S. Norton, "Through the Eyes of a Child: An Introduction to Children's Literature (8th)," Columbus, Ohio Merrill. Ricardo, S, 1999.

[13] G. N. Rohmah, "Pengaruh Nilai Cerita Anak dan Kesusasteraan dalam Menciptakan Pendidikan Humanis Bagi Anak Indonesia,” Ling. J. Ilmu Bhs. dan Sastra, vol. 1, no. 1, 2006.

[14] D. D. Nufus, "Pengembangan Buku Pengayaan Cerita Anak Berbahasa Jawa Berbasis Pendidikan Karakter dalam Lingkungan Keluarga.” Universitas Negeri Semarang, 2013.

[15] W. K. Ikhwan, "Upaya Menumbuhkan Karakter Anak dalam Pembelajaran Sastra Anak dengan Model Play-Learning dan Performance-Art Learning di SDN Banyuajuh 4," Widyagogik J. Pendidik. dan Pembelajaran Sekol. Dasar, vol. 1, no. 1, pp. 70-84, 2013.

[16] A. Bryman, Social research methods. Oxford university press, 2016.

[17] M. Septiasputri, "Kehadiran 'Bobo' Tidak Lepas Dari Jakob Oetama. Rri.co.id.," RRI, 2020. [Online]. Available: https://rri.co.id/humaniora/info-publik/895322/kehadiran-bobo-tidak-lepasdari-jakoboetama.

[18] BBC Indonesia, "Dieng dan 'misteri' kompleks candi kuno: Apa bukti Dieng sebagai pusat ritual dan pendidikan agama?," BBC Indonesia, 2020. [Online]. Available: https://www.bbc.com/indonesia/indonesia-53619707.

[19] J. Romain, "Indian architecture in the 'Sanskrit cosmopolis': The temples of the Dieng plateau," Early Interact. between South Southeast Asia Reflections Cross-Cultural Exch., pp. 299-316, 2011.

[20] A. Febriyanto, S. Riawanti, and B. Gunawan, "Mitos Rambut Gimbal: Identitas Budaya dan Komodifikasi di Dataran Tinggi Dieng," Umbara, vol. 2, no. 1, 2018.

[21] P. T. Suzuki, Critical survey of studies on the anthropology of Nias, Mentawei and Enggano, vol. 3. Springer Science \& Business Media, 2013.

[22] A. Z. Siregar and S. Syamsuddin, "Tradisi Hombo Batu di Pulau Nias: Satu Media Pendidikan Karakter Berbasis Kearifan Lokal," SIPATAHOENAN, vol. 1, no. 2, 2015.

[23] B. L. Harefa, "Mamözi Aramba, Faritia, dan Göndra," Kabar Nias, 2015. [Online]. Available: https://kabarnias.com/budaya/mamozi-aramba-faritia-dan-gondra-1074.

[24] C. T. Telaumbauna, "Analisis Sinunő Pada Pertunjukan Fanari Ya'Ahowu Dalam Kebudayaan Nias Di Kota Gunungsitoli,” Universitas Sumatera Utara, 2012.

[25] R. Ricardo, "Menyeruput Hangatnya Mi Ongklok di Dinginnya Udara Dieng," Republika.co.id, 2019. [Online]. Available: https://republika.co.id/berita/gayahidup/kuliner/19/10/14/pzchsz142911001119000-menyeruput-hangatnya-mi-ongklok-didinginnya-udara-dieng. 